Northwestern University School of Law Northwestern University School of Law Scholarly Commons

Faculty Working Papers

1994

\title{
Peace vs. Accountability in Bosnia
}

Anthony D'Amato

Northwestern University School of Law, a-damato@law.northwestern.edu

\section{Repository Citation}

D'Amato, Anthony, "Peace vs. Accountability in Bosnia" (1994). Faculty Working Papers. Paper 139.

http://scholarlycommons.law.northwestern.edu/facultyworkingpapers/139

This Article is brought to you for free and open access by Northwestern University School of Law Scholarly Commons. It has been accepted for inclusion in Faculty Working Papers by an authorized administrator of Northwestern University School of Law Scholarly Commons. 


\title{
Peace vs. Accountability in Bosnia, by Anthony D’Amato,*
}

88 American Journal of International Law 500-506 (1994)

\begin{abstract}
Hovering over the peace negotiations in progress in former Yugoslavia is the international community's determination to bring to trial as war criminals those political and military leaders responsible for atrocities in Bosnia. The question clearly presented is that, however desirable the idea of war crimes accountability might appear in the abstract, pursuing the goal of a war crimes tribunal may simply result in prolonging a war of civilian atrocities. Is it not conceivable that, in return for securing a peace treaty, the UN officials may have extended some assurance to the leaders in former Yugoslavia that, one way or another, war crimes trials will not take place?
\end{abstract}

Tags: Bosnia, War Crimes Tribunal (former Yugoslavia), War Criminals

[pg500]** Peace negotiations, amid continued hostilities, are in progress in former Yugoslavia at the time of this writing. Hovering over the negotiations is the international community's determination to bring to trial as war criminals those political and military leaders responsible for atrocities in Bosnia, including rape [FN1] and "ethnic cleansing." The United Nations rapporteur for the establishment of the Yugoslav war crimes tribunal, M. Cherif Bassiouni, has articulated on numerous occasions the international community's determination to prosecute war criminals on all sides of the three-cornered war in Bosnia. However, some of the Serbian, Muslim and Croatian political and military leaders who are potential targets of the tribunal are participating in the peace negotiations. Is it realistic to expect them to agree to a peace settlement in Bosnia if, directly following the agreement, they may find themselves in the dock? If they, or their close associates and friends, face potential life imprisonment by simply signing a peace treaty, what incentive do they have to sign it?

Sometimes international scholars have to proceed by inferring negotiations in the absence of an evidentiary record. How are we to know whether some United Nations officials, in their numerous and usually unrecorded meetings with Serbian, Muslim and Croatian leaders, may have privately acknowledged that it is unrealistic to expect a peace treaty in light of subsequent prosecutions for war crimes? Is it not at least conceivable that, in return for securing a peace treaty, the UN officials may have extended some form of assurance to the leaders in former Yugoslavia that, one way or another, the war crimes trials will not take place?

If such assurances are being proffered in the Bosnian negotiations, they would of necessity have to be highly secret. World public opinion might not tolerate the idea of war criminals' being able to bargain their way out of prosecution for their crimes. Further complicating the issue is the fact that the United Nations officials engaged in the negotiations for peace in former Yugoslavia do not themselves have the authority to waive the right of the United Nations to prosecute war criminals. That right seems firmly established in the Security Council under chapter VII of the UN Charter.[FN2] Only the Council itself could trade its right to prosecute war criminals in former Yugoslavia in return for a final peace settlement in that troubled region. But even at the level of the Security Council, any such deal would probably have to be hidden under a veil of diplomatic secrecy, since the deal would presumably be severely criticized in the world 
media. Yet the incentive for the Security Council to countenance such a deal is strong. For it may be justified on the ground that it is better to stop the bloodshed of innocent civilians in former Yugoslavia than to insist on punishing war criminals. Securing peace in Bosnia may seem to the UN officials to be preferable to achieving individual accountability for war crimes. In broad but perhaps misleading terms, peace may here seem more important than justice.

There is scant historical precedent for the apparently novel dilemma of attempting to achieve a peace treaty when some of the negotiators themselves are in [pg501] jeopardy of being prosecuted as war criminals. Is there any lesson to be derived from the successful establishment of the Nuremberg and Far East Tribunals following the Second World War? The Allies had insisted upon "unconditional surrender," an insistence that in retrospect may have unnecessarily prolonged the war by giving little, if any, incentive to Axis political and military leaders to sue for peace. In Europe there were no peace negotiations; the war ended when Hitler was killed and most of the Nazi leaders were captured. Following the German capitulation, various "peace feelers" issued from Tokyo, but again there were no formal peace negotiations. The Allies seemed to reject the idea of peace negotiations as inconsistent with unconditional surrender. After the horror of the atomic bombs dropped on Hiroshima and Nagasaki, peace was rapidly negotiated and the idea of totally unconditional surrender was finally dropped, at least insofar as Japan was allowed to keep its emperor. Overall, there was little, if any, opportunity either in Europe or in the Far East for any of the Axis leaders to attempt to place the matter of war crimes tribunals on the bargaining table. Moreover, it is not clear how many of the remaining leaders were aware of the Allies' determination to proceed with postwar criminal accountability. Indeed, the Allies themselves were not of one mind on this subject; there was considerable debate regarding the desirability of the Nuremberg Tribunal in the United States, and the Soviet Union was opposed to the idea.

In the aftermath of Nuremberg, the very real possibility of individual responsibility for war crimes, coupled with the fact that there has been no "unconditional surrender" war since 1945, may account for the conspicuous absence of international tribunals following the Korean War, the Vietnam War, the wars involving Israel, and other international conflicts. During the Persian Gulf war, the idea of holding trials of Iraqi political and military leaders was raised and debated in Congress, [FN3] but nothing eventually came of it. Here the United Nations forces certainly had it within their power to set up such a tribunal, and many of the Iraqi military leaders were in captivity. It may be a long time before we get documentary evidence on who decided to drop the idea of prosecuting the Iraqi war criminals. Perhaps some American military leaders feared their own prosecution for inaccuracy in the bombing of Baghdad, and thus there was little incentive to pursue the idea of a war crimes tribunal. But whatever the reasons, the failure of the international community to set up such a war crimes tribunal, when it had the means and ability to do so, must be counted as a significant negative precedent for international accountability.

The conditions in Bosnia are even less favorable for a war crimes tribunal than they were after the Persian Gulf war. Unlike the Iraqi military leaders responsible for war 
crimes in Kuwait, the persons allegedly responsible for war crimes in Bosnia are still at large and indeed are present—or their friends are present—at the peace negotiations.

Nor is there any element of surprise, as there may have been at Nuremberg. The idea of international war crimes accountability is surely conspicuous to the political and military leaders currently negotiating for peace in former Yugoslavia. It is only human to expect them to insist privately on immunity as a condition for peace. It is possible that the United Nations has sent a signal to the leaders in former Yugoslavia that the war crimes tribunal might fail for lack of funding. For [pg502] the United Nations has so far allocated only a small fraction of the costs of the tribunal. Even so, using the budget to undercut a program in place is a shaky proposition (although governments are quite adept at doing such things internally). Professor Bassiouni has had some success in obtaining private donations to fund his extensive computerized compilation of evidence of war crimes. Who is to say that private donors might not come forth to pay the costs of the war crimes tribunal even if the United Nations would prefer to let the idea die for lack of funding?

But none of these financial considerations go to the heart of the policy dilemma facing the international community. The question clearly presented is that, however desirable the idea of war crimes accountability might appear in the abstract, pursuing the goal of a war crimes tribunal may simply result in prolonging a war of civilian atrocities. This would surely be a paradoxical result, for the idea of war crimes accountability is to deter the commission of war crimes and not to serve as a barrier to discontinuing them.

Let us examine more closely the precise interest in securing individual accountability for war crimes. Consider the analogous case of settlement discussions in a complex domestic tort litigation. Courts strongly encourage parties to settle their case on their own terms. Rarely is there judicial interference with the terms of the settlement, an exception being the occasional supervision of attorneys' fees in class action settlements. The reason for judicial abstention, even in cases of product liability resulting in wrongful death, is that judges feel that the parties can achieve exact justice in their private negotiations. Judges do not believe that there is any component of "social justice" that has to be inserted into the settlement negotiations by the court. Indeed, the prevailing judicial attitude that the parties can achieve exact justice among themselves is so strong that courts typically will allow the parties, if it is one of the settlement conditions, to conceal the terms of the settlement.

Applying the domestic tort model to the Bosnian peace process might lead us to conclude that the warring parties can achieve perfect justice among themselves, and that there should be no real independent international interest in the matter. Surely the parties are aware of the war crimes and atrocities that were committed during the course of the war. Surely they can make adjustments in the terms of the peace treaty as compensation for these crimes. If an impending Yugoslav war crimes tribunal in their view constitutes an impediment to a peace settlement (because of the negotiators' personal fear of indictment), then a settlement to achieve justice inter se would be subverted by their fear of criminal prosecution. 
But is domestic tort litigation the appropriate model? Suppose A murders B, and B's heirs sue A in tort. Suppose further that A is wealthy, and offers B's heirs ten million dollars in damages. B's heirs regard this as a generous offer, and they accept it. Yet if A insists, as part of the settlement, that his prosecution for murder must be dropped, B's heirs will correctly reply that, although they may be willing to bargain away the criminal prosecution, they have no power to do so. In other words, there is a state interest in prosecuting the murderer above and beyond the victim's interest in full compensation.

The state's interest is largely summed up in the term "deterrence." Deterrence is an interest that is logically independent of the interests of A and B. As A, the murderer, obviously was not deterred, punishing him has no deterrent effect upon him; the purpose of punishing him is solely to provide an example to others. $\mathrm{B}$, the victim, is similarly unaffected by deterrence; obviously his murder was not [pg503] deterred. Applying this reasoning to the Bosnian situation, it may well be that, although the parties can secure perfect justice among themselves in their private peace negotiations, an international interest exists that is above and beyond the interests of the parties. The international interest consists of deterring would-be war criminals. This interest may be quite irrelevant to the victims of the atrocities in Bosnia, but it is forward-looking in its attempt to deter similar atrocities in future conflicts.

This line of reasoning seems to take us further into a dilemma. If we posit an international interest in deterrence that is above and beyond the interests of the parties in the peace negotiations, we face the problem that the leaders of former Yugoslavia may simply refuse to sign a treaty of peace that will jeopardize them personally. Even if they accept the logic of deterring future war criminals, they still can be presumed to be driven primarily by the practical motive of self-preservation. But the dilemma deepens because the international community cannot exempt specific individuals from war crimes prosecution on the ground that they were either present at the peace negotiations or had political clout with the negotiators. It would simply be unacceptable to immunize leaders while prosecuting their subordinates for war crimes. For if immunity were given to the leaders, their subordinates would at trial claim superior orders in mitigation of their offense. To prove their claim, the defendants would offer evidence of orders issued by the very people who have immunity. Those people would be called as witnesses, and the world would be treated to a repeated spectacle of witnesses shown to be more culpable than the accused. Such a trial might be considerably worse than having no trial at all.

It is difficult to see a practical way out of the dilemma. However, a theoretical solution is conceivable. It is one that might excite interest among law-and-economics scholars who regard everything in life as having a monetary price. The solution is as follows: the United Nations would tell the warring parties to the Bosnian conflict that the international war crimes tribunal will proceed unless the Muslims, Croats and Serbs agree inter se in their peace negotiations to ask the United Nations to dissolve the tribunal-a request that the Security Council will grant. By thus delegating the decision on war crimes prosecution to the antagonists themselves, the United Nations would have put the tribunal in play as an explicit bargaining chip in the peace negotiations. 
Many readers may find this solution distasteful, as I do. Yet it deserves impartial analysis. First, offering the tribunal as a bargaining chip would remove the practical impediment to peace, for it is only natural to assume that the leaders in former Yugoslavia can be expected to arrive at a peace treaty if they do not personally face subsequent prosecution as war criminals. Second, offering the tribunal as a bargaining chip may achieve most of the deterrence objectives that we previously postulated as an independent interest of the international community.

To illustrate this second point, let us assume that the parties agree among themselves that each was responsible for one-third of the war crimes and that each was the victim of one-third of the war crimes. They might then agree as part of the peace treaty that there should be no war crimes tribunal. Because each of them suffered equally from the commission of war crimes that they equally perpetrated, the suffering they sustained was in effect a punishment that fit their crimes.

Of course, it is unlikely that responsibility and suffering would be apportioned so equally. It is more likely that one of the parties committed more war crimes than the others, and that the others therefore suffered disproportionately more [pg504] than the first party. In that case, the first party would have a greater interest than the other two parties in eliminating a war crimes tribunal. Because the first party has this greater interest, the other two parties ipso facto gain a bargaining advantage. For the two victimized parties will argue in the peace negotiations that, although they would be jeopardized to some extent as perpetrators if indicted by a war crimes tribunal, the first party would be in far greater jeopardy. Hence, the first party has more to lose than they do. The victimized parties would probably add that a war crimes tribunal is necessary to redress the imbalance and thus avenge the greater suffering of their own people. In short, the bargaining chip has become an asset of the two victimized parties. For the first party to secure their agreement to the elimination of the war crimes tribunal as part of an overall peace settlement, the first party would have to give up some other asset in exchange. That asset could very well be a portion of the disputed Bosnian territory currently in the control of the first party.

Here we see how the international interest has been folded into the peace negotiations. The international interest consists of deterring future war criminals. This deterrence can theoretically be secured by making the tribunal a bargaining chip. If the first party has to give up land to get the other two parties to agree to the elimination of the war crimes tribunal, that concession becomes a very real cost that the first party incurred for its commission of war crimes. Political and military leaders in future wars would thus be subject to a double-barreled uncertainty: their own possible prosecution as war criminals in the event that the peace process does not result in an agreement to eliminate the war crimes tribunal, or possible loss of valued territory so as to obtain agreement during the peace negotiations to eliminate the tribunal.

What appears distasteful about this theoretical solution is perhaps best illustrated by a return to the domestic law analogy. If B's heirs were permitted to bargain away the state's 
right to prosecute A, presumably A would pay a higher amount in damages to secure their waiver of criminal charges. But domestic law retains its independent right to proceed criminally against $\mathrm{A}$, on the general principle that there is a societal interest in deterrence that is not necessarily included within the calculus of the victim's interest. Yet arguably, if the state's interest is one of deterrence, an economic analysis could work here as well. The higher price that A would have to pay to B's heirs to get their waiver of prosecution should operate to deter future As just as much as imprisonment of A would deter future As. The deterrence would be equal because the amount of money that A pays to B's heirs will be equal (in theory at least) to the value to A to avoid being imprisoned. A future person in A's position would thus be deterred either by imprisonment or by its equivalent value in dollars. Why, then, does domestic law not allow victims to bargain away the state's right to prosecute?

One important reason may be the empirical fact that most criminals lack sufficient assets to compensate their victims. Although we can imagine that a criminal who has ten million dollars would be deterred by the prospect of having to pay his victim ten million dollars, the criminal who has only ten dollars would not be deterred by the prospect of having to pay his victim ten million dollars. Nor could the criminal justice system operate on two tracks: imprisoning the impecunious criminals while allowing the wealthy criminals to buy their way out of jail. But if all criminals had sufficient assets to compensate their victims - a most unlikely prospect - then perhaps society would opt for a system of victims' bargaining away the state's right to prosecute. (Something like this bargaining principle for criminal [pg505] delicts obtained among the patricians under ancient Roman law - each person in that class had sufficient assets to be deterred by the threat of having to pay full compensation.) It is arguable today that a compensatory system would do a lot more for the victims of crime than putting the criminal in jail where he does no good to the victims and burdens society (including the victims as taxpayers) with the costs of incarceration.

Although it is most unlikely for a domestic system ever to consist of citizens who each have that degree of wealth, in international peace negotiations the opposite is true. All parties to the peace negotiations have assets that the other side desires. This statement is a truism, for the very existence of a war betokens the fact that both sides of the conflict have assets that the warring parties are trying to acquire by force. These assets, then, constitute bargaining chips in the peace negotiations.

We now see the critical importance for the international community to mount a credible threat of war crimes prosecutions. The peace negotiators must have a realistic fear of being prosecuted if the war crimes tribunal is to become a credible bargaining chip. If there were no impending possibility of prosecution, the party that committed a disproportionate amount of the war crimes would simply have no incentive to give away any land or any other assets for any reason connected to the commission of war crimes.

I am not advocating the "bargaining chip" approach to the Yugoslav war crimes tribunal so much as trying to understand the possibility that something like this process, hidden from our notice, may be happening at present. If the United Nations is 
downplaying the tribunal (for example, by giving it only trivial financial support), it may be actuated by a diplomatic insight that insisting upon a tribunal has the practical effect of prolonging the war. But if in fact the United Nations is (secretly) prepared to abandon the war crimes tribunal in order to catalyze peace in the Balkans, the process may not have been fully thought through. How indeed could the tribunal be abandoned? Simply cutting off its funding, as I suggested above, might not do it. And what about the difficulty of persuading world public opinion, which at present is clearly in favor of proceeding to the prosecution of war criminals? How can the Security Council's approval be sought in the glare of world publicity? These considerations feed into the main dilemma like tributaries feeding into a river; the result may be a muddying of the waters. Some United Nations officials may be proceeding under the assumption that the tribunal cannot be negotiated away, while others may be in the process of giving it away without getting anything in return. This possible lack of institutional clarity could itself result in an unnecessary prolongation of the brutal war in Bosnia.

I suggest that there may be something to gain if the Security Council would explicitly agree to eliminate the tribunal on the condition that the Muslims, Croats and Serbs sign a comprehensive peace treaty for former Yugoslavia. The party committing more war crimes would have to make land concessions to the other parties, but no individual signatory would face prosecution. This may be the simplest and most direct route to peace in the Balkans.

There is one rather neat theoretical payoff in this economic approach to war crimes tribunals. The approach, as we have seen, takes an externality-namely, the international community's interest in prosecuting war criminals - and internalizes it into the peace negotiation process by allowing it to be used as a bargaining chip. In effect, this transforms a war crime into a cost of war. A commander who commits a war crime during a war incurs a cost so as to obtain immunity from subsequent prosecution-a cost consisting of giving up some of the assets that the [pg506] war itself was designed to acquire. In this fashion a war crime loses its military justification. Whatever advantages it might have had, such as the alleged advantage of terrorizing the opposing side, are forfeited where it counts-in the final reckoning of the peace settlement. We therefore see a vindication of the classic theory of war crimes - that they are not justified by military necessity. By internalizing the costs of the commission of war crimes, international law will be able to bring to a successful conclusion the theory that war crimes are not required by, and indeed are counterproductive to, military necessity.

\section{Footnotes}

*Copyright (C) 1994 by ASIL; Anthony D'Amato

**Numbers in the format "pg500” etc. refer to the pagination of the original article.

[FN1]. See Theodor Meron, Rape as a Crime under International Humanitarian Law, 87 AJIL 424 (1993). 
[FN2]. See Paul Szasz, The Proposed War Crimes Tribunal for Ex-Yugoslavia, 25 N.Y.U. J. INT'L L. \& POL. 405 (1993); see generally Theodor Meron, War Crimes in Yugoslavia and the Development of International Law, 88 AJIL 78 (1994).

[FN3]. I testified in April 1991 before the Senate Foreign Relations Committee in favor of the establishment of a war crimes tribunal. 